\title{
Phytophthora ramorum as the Cause of Extensive Mortality of Quercus spp. and Lithocarpus densiflorus in California
}

\author{
D. M. Rizzo, Department of Plant Pathology, University of California, Davis 95616; M. Garbelotto, Department of \\ Environmental Science, Policy and Management, Ecosystem Science Division, University of California, Berkeley \\ 94720; J. M. Davidson and G. W. Slaughter, Department of Plant Pathology, University of California, Davis; and \\ S. T. Koike, University of California Cooperative Extension, 1432 Abbott Street, Salinas, CA 93901
}

\begin{abstract}
Rizzo, D. M., Garbelotto, M., Davidson, J. M., Slaughter, G. W., and Koike, S. T. 2002. Phytophthora ramorum as the cause of extensive mortality of Quercus spp. and Lithocarpus densiflorus in California. Plant Dis. 86:205-214.

A new canker disease, commonly known as sudden oak death, of Lithocarpus densiflorus, Quercus agrifolia, Q. kelloggii, and Q. parvula var. shrevei in California is shown to be caused by Phytophthora ramorum. The pathogen is a recently described species that previously was known only from Germany and the Netherlands on Rhododendron spp. and a Viburnum sp. This disease has reached epidemic proportions in forests along approximately $300 \mathrm{~km}$ of the central coast of California. The most consistent and diagnostic symptoms on trees are cankers that develop before foliage symptoms become evident. Cankers have brown or black discolored outer bark and seep dark red sap. Cankers occur on the trunk at the root crown up to $20 \mathrm{~m}$ above the ground, but do not enlarge below the soil line into the roots. Individual cankers are delimited by thin black lines in the inner bark and can be over $2 \mathrm{~m}$ in length. In $L$. densiflorus saplings, $P$ ramorum was isolated from branches as small as $5 \mathrm{~mm}$ in diameter. L. densiflorus and Q. agrifolia were inoculated with $P$. ramorum in the field and greenhouse, and symptoms similar to those of naturally infected trees developed. The pathogen was reisolated from the inoculated plants, which confirmed pathogenicity.
\end{abstract}

Additional keywords: canker disease, exotic pathogen

Over the past 7 years, a previously undescribed disease of tanoak (Lithocarpus densiflorus), coast live oak (Quercus agrifolia), and California black oak (Q. kelloggii) has been reported from central California $(12,20)$. The disease has been associated with very high mortality of trees in wildlands and the urban-wildland interface (Fig. 1) and is primarily found in coastal regions just north and south of the San Francisco Bay. Named "sudden oak death" in the popular press, the whole crown of affected trees often appears to die

Corresponding author: D. M. Rizzo

E-mail:dmrizzo@ucdavis.edu

Accession number: GenBank AY038050.

This research has been partially funded by a cooperative agreement with the USDA Forest Service, the Agricultural Commissioner's Office of Monterey County, Big Creek Lumber, Central Coast Forest Association, Pacific Gas \& Electric Company's Contributions Program, and the Post Ranch.

Accepted for publication 8 November 2001.

Publication no. D-2002-0115-01R

(C) 2002 The American Phytopathological Society rapidly; the foliage may turn from a healthy green color to brown over a period of several weeks $(12,20)$. There have been previous reports of high levels of oak mortality associated with extended periods of drought in California $(16,29)$, but the current extent and level of mortality appear to be unprecedented in recent history.

The most consistent and diagnostic symptom of the disease on larger trees is the development of cankers that have brown or black discolored outer bark on the lower trunk and that seep dark red sap (Fig. 2) (12). These cankers develop before foliage symptoms become evident (12). Such discoloration and bleeding are common symptoms associated with infection by Phytophthora spp. on oaks $(5,21,28)$. Consistent with this observation, we isolated a species of Phytophthora from diseased L. densiflorus and Quercus spp. in Marin County during June 2000 (12). Subsequently, we recovered this pathogen throughout the range of the reported tree mortality; Phytophthora consistently was associated with bleeding cankers on the trunk and rapid browning of foliage (12).

Several Phytophthora spp. are known to cause oak mortality. Phytophthora cinnamomi has been implicated in large-scale oak mortality in native forests of southern Europe $(2,5,10,24)$ and central Mexico (28). In California, P. cinnamomi, P. cactorum, and $P$. citricola have been shown to cause root and crown rot in landscape and ornamental plantings of oak (21). These pathogens often have been associated with wet soils found in low-lying areas or overirrigated sites. In contrast, the distribution of this new Phytophthora sp. in natural forests of coastal California lacked a strict association with saturated soils or the presence of water (12). Symptomatic trees have been observed on dry hillsides and ridge tops. Furthermore, typical cankers appeared exclusively on the trunk and branches of infected trees (12), rather than in the roots, where infections are commonly initiated by most of the other species of Phytophthora associated with oaks.

The objectives of this study were to determine the etiology and distribution of this new canker disease of $L$. densiflorus and Quercus spp. Our results indicate that a new species of Phytophthora, P. ramorum, is consistently associated with the current extensive oak mortality in central coastal California, and that its pattern of attack is distinct from that of other known Phytophthora spp. causing disease of oaks.

\section{MATERIALS AND METHODS}

Field survey. Symptomatic and dead trees were located based on reports from farm advisors, Cooperative Extension specialists, California Department of Forestry personnel, United States Department of Agriculture Forest Service pathologists, arborists, researchers, and homeowners. At each site, samples were collected from individual trees that had symptoms characteristic of Phytophthora infection, and the samples were taken to the laboratory for isolation.

Specific locations of sampled trees were noted using global positioning system (GPS) equipment (Trimble Corp., Sunnyvale, CA) and entered into a monitoring database maintained by Dr. Maggi Kelly, University of California, Berkeley. Additional data collected with each sample included host species, description of symptoms, tree diameter at $1.4 \mathrm{~m}$ above ground 


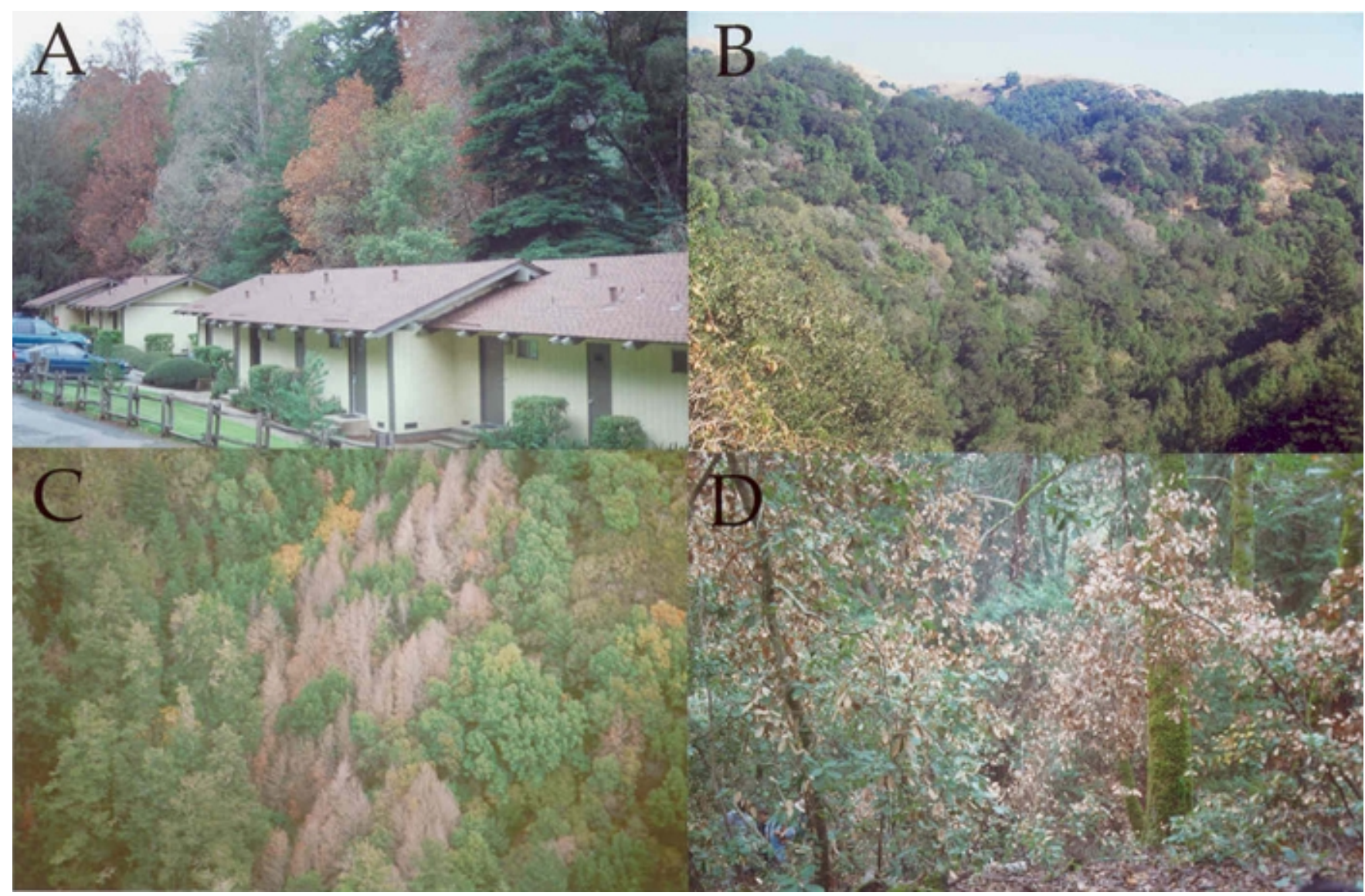

Fig. 1. Examples of mortality of forest trees in California caused by Phytophthora ramorum. A, Mortality of Quercus agrifolia and Lithocarpus densiflorus in Pfeiffer Big Sur State Park, Monterey County. B, Mortality of Q. agrifolia and Q. kelloggii in a mixed evergreen forest in Marin County. Additional overstory species in the area include Umbellularia californica, Arbutus menziesii, and Pseudotsuga menziesii. C, Dead and dying overstory L. densiflorus in a Douglas fir-tanoak forest in Marin County. Trees to the left of the dead L. densiflorus are mostly P. menziesii; trees to the right include A. menziesii and Acer macrophyllum. D, Mortality of L. densiflorus saplings in the understory of a redwood forest in Marin County.

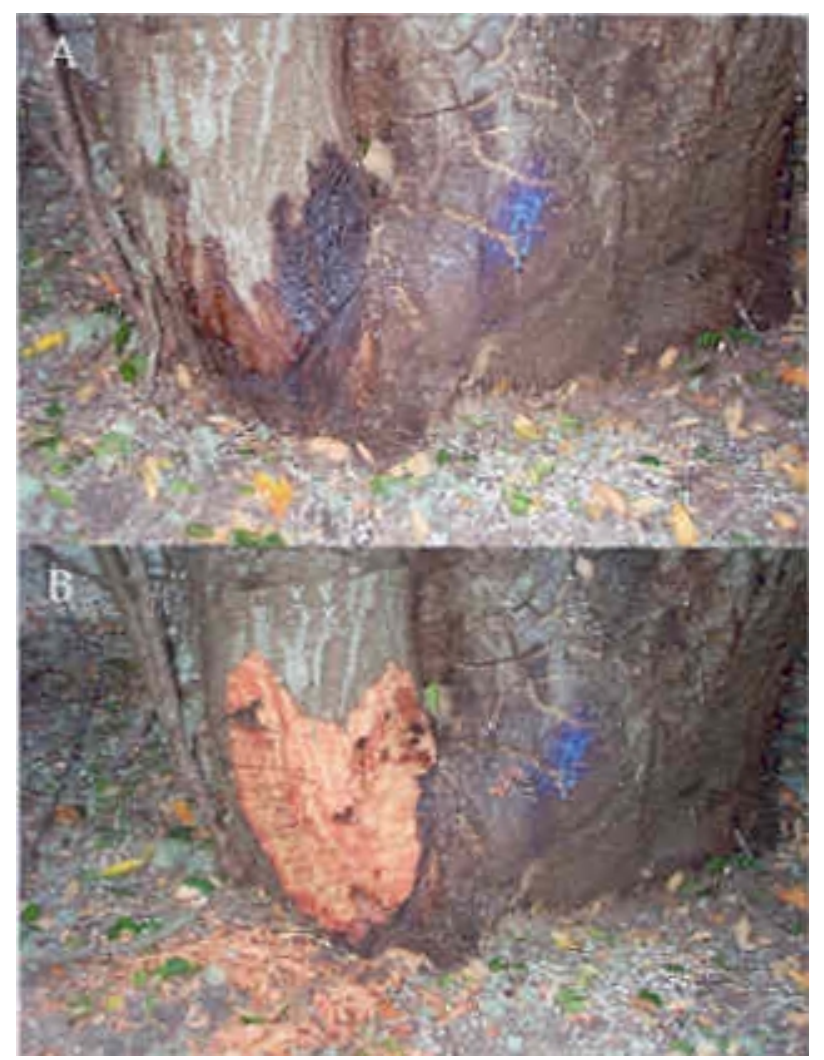

Fig. 2. Symptoms of infection by Phytophthora ramorum on Quercus agrifolia. A, Bleeding canker on lower trunk just above soil line. B, Same canker with outer bark removed to show canker margin in phloem.

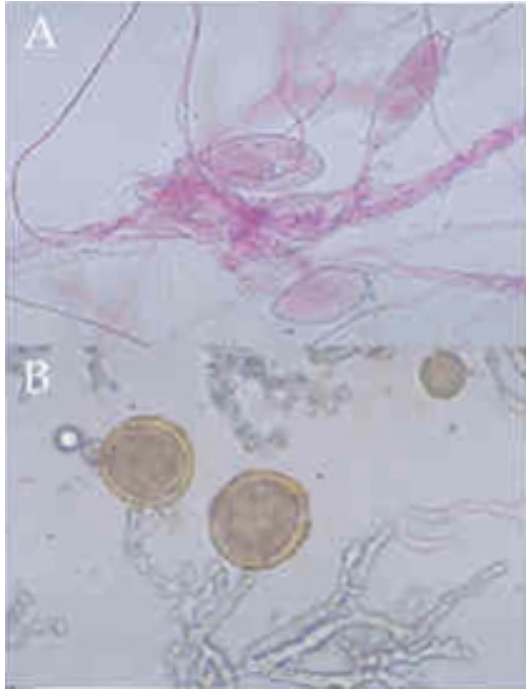

Fig. 3. Microscopic characters of Phytophthora ramorum. A, Semipapillate sporangia. Sporangia in upper right has germinated directly. Sporangia are approximately $60 \mu \mathrm{m}$ in length. B, Typical thickwalled, pigmented chlamydospores. Chlamydospores are approximately $80 \mu \mathrm{m}$ in diameter. 
(diameter at breast height, dbh), forest type, overall stand health, and the location of the sampled trees relative to other symptomatic trees. Where possible, samples were collected from several trees at each location.

Pathogen isolation and identification. Samples were taken from trees with bleeding cankers by cutting into the inner bark in the area directly around the oozing sap until a canker margin was evident (Fig. 2). For understory tanoaks showing branch dieback, bark was removed from affected shoots to reveal discolored lesions. Pieces of phloem and xylem were removed from canker and lesion margins and placed in petri dishes (either in the laboratory or in the field) containing pimaricin-ampicillinrifampicin-PCNB agar (PARP), a selective medium for Phytophthora spp. (8). Pimaricin was used at a concentration of 10 $\mu \mathrm{g} / \mathrm{ml}$ (8). Plates were incubated in the dark at 20 to $22^{\circ} \mathrm{C}$ and examined within 2 to 5 days. Mycelia of Phytophthora spp. were transferred to corn meal agar (CMA; Difco Laboratories, Detroit, MI) and V8 juice agar (V8A) and morphologically compared with descriptions of described species (8). Plates were incubated in both constant dark and alternating light $(12 \mathrm{~h})$ and dark $(12 \mathrm{~h})$ at 20 to $22^{\circ} \mathrm{C}$. All Phytophthora isolates initially were grouped based on morphological characters. A subset of isolates of each morphotype then was selected for DNA sequence analysis. All cultures are maintained at the University of California, Davis in screw-cap tubes on V8A in the dark at 20 to $22^{\circ} \mathrm{C}$. Voucher cultures have been submitted to the American Type Culture Collection (ATCC) and the Phytophthora Collection at the University of California, Riverside.

DNA was extracted from cultures growing on CMA by harvesting the hyphal mat after microwaving the petri dish for $1 \mathrm{~min}$ to melt the agar. The mat was blotted carefully with filter paper to eliminate the agar, and DNA was extracted as described in Garbelotto et al. (11). The internal transcribed spacer (ITS) regions, including the 5.8S gene of the nuclear ribosomal DNA (rDNA), were amplified in a Techne PHC100 thermocycler using the primers ITS1 and ITS4 (34). An initial polymerase chain reaction (PCR) cycle of $1 \mathrm{~min}$ and 25 $\mathrm{s}$ at $94^{\circ} \mathrm{C}$ was followed by 34 cycles of 35 $\mathrm{s}$ at $93^{\circ} \mathrm{C}, 55 \mathrm{~s}$ at $62^{\circ} \mathrm{C}$, and $50 \mathrm{~s}$ at $72^{\circ} \mathrm{C}$. The $72^{\circ} \mathrm{C}$ extension period was extended for $5 \mathrm{~s}$ at each cycle with a final extension at $72^{\circ} \mathrm{C}$ for $10 \mathrm{~min}$. Sequences of the complimentary strands were obtained using an ABI 377 automatic sequencer (Applied Biosystems, Foster City, CA). Sequence alignments were obtained by using Sequencher software (GeneCodes, Ann Arbor, MI) and optimized by manual alignment. Using the consensus sequences, we performed a BLAST search of the GenBank database (NCBI, National Institutes of Health, Bethesda, MD). In addition, our consensus sequences were aligned with those of 44 species of Phytophthora using the alignment available in GenBank as a template (PopSet number 8927467, NCBI) (6). The aligned database was analyzed by both the parsimony and distance matrix methods available in PAUP (ver. 4.0b2; 27). Parsimony analysis was conducted using the heuristic search option and random addition. Gaps were treated as missing data. Bootstrap values were obtained by 1,000 replicates of the "fast" stepwise addition method.

Seedling and sapling inoculation trials. Two greenhouse trials were conducted on 20- to 24-month-old L. densiflorus and Q. agrifolia seedlings (stem diameter approximately $1 \mathrm{~cm}$ ) to determine pathogenicity of the most commonly isolated species of Phytophthora. Inoculum was prepared by growing two isolates (PR-5 and PR-6; Table 1) on V8A for 7 days in the dark at 20 to $22^{\circ} \mathrm{C}$, then removing 5mm-diameter plugs from the advancing margin of the mycelium using a sterilized cork borer. On each seedling tested, one shallow cut, approximately $5 \mathrm{~cm}$ above the soil line, was made into the bark of the main stem to create a narrow (5 to $8 \mathrm{~mm}$ wide), attached flap of bark. A colonized each seedling, the flap was put back into place, and the inoculated wound was sealed by wrapping with parafilm. Control seedlings were inoculated similarly with a sterile agar plug.

Seedlings were incubated in a greenhouse that was maintained at 20 to $22^{\circ} \mathrm{C}$. The trials took place during 12 September to 16 November 2000 (65 days) and 9 June to 18 July 2001 (40 days), respectively. In both trials, 10 seedlings of each host species were inoculated with each isolate and with sterile agar. At the end of the experiment, symptoms were recorded, lesion length and width were measured, and pieces of the stem segment were plated on PARP to verify presence or absence of Phytophthora. Plates were incubated in the dark at 20 to $22^{\circ} \mathrm{C}$ and examined within 2 to 5 days.

Three greenhouse trials were conducted on 3- to 4-year-old $Q$. agrifolia saplings to determine pathogenicity of the Phytophthora sp. The saplings were 2 to 5.2 $\mathrm{cm}$ in diameter (mean $3.5 \mathrm{~cm}$ ) and 3 to $5 \mathrm{~m}$ tall. In each trial, five saplings were inocuagar plug was inserted beneath the flap on

lated with Phytophthora isolate PR-5 and five with sterile agar. Inoculations were performed as described above at approximately 50 to $60 \mathrm{~cm}$ above the soil line. The trials took place during 12 August 2000 to 3 March 2001 (204 days), 31 October 2000 to 3 March 2001 (125 days), and 4 April 2001 to 1 September 2001 (150 days). At the end of the experiment, symptoms were recorded, saplings were debarked, lesion length and width were measured, and pieces of the stem segment were plated on PARP to verify presence or absence of Phytophthora. Plates were incubated in the dark at 20 to $22^{\circ} \mathrm{C}$ and examined within 2 to 5 days.

All data were analyzed by analysis of variance (ANOVA) using the software program JMP (25). Where necessary, dependent variables were transformed or the ANOVA was weighted by the inverse of the variance of the residuals to control for unequal variance among treatment means (19).

Mature tree inoculation trials. Ten trees each of L. densiflorus and $Q$. agrifolia were inoculated on the Marin Municipal Water District on 26 July 2000. The $L$. densiflorus trees were located in a coast redwood forest. The $Q$. agrifolia trees were located in a closed-canopy, mixedevergreen forest. Many trees were naturally infected and symptomatic at both sites; the selected trees, however, showed no visible symptoms of Phytophthora infection (i.e., no bleeding cankers) and were apparently healthy. Average diameters at $1.4 \mathrm{~m}$ above the ground (dbh) were 34.6 $\mathrm{cm}$ for $L$. densiflorus and $26 \mathrm{~cm}$ for $Q$. agrifolia.

Trees were inoculated using the technique of Tainter et al. (28). Inoculum was prepared by growing one of two isolates (PR-5 and PR-6) on V8A for 7 days in the dark at 20 to $22^{\circ} \mathrm{C}$, then removing $1-\mathrm{cm}-$ diameter plugs from the advancing margin of the mycelium with a sterile cork borer. There were three inoculations per tree: isolates PR-5, PR-6, and a control. Bark plugs were removed at approximately 1.4 $\mathrm{m}$ above the ground by using a sterile cork borer ( $1.2 \mathrm{~cm}$ in diameter) inserted into the tree until it came in contact with the xylem. Agar plugs of Phytophthora cultures or sterile agar were inserted into the wounds. Inoculation points were approximately 20 to $30 \mathrm{~cm}$ apart around the cir-

Table 1. Origin of isolates of Phytophthora ramorum from California used in inoculation trials and DNA sequence analysis

\begin{tabular}{lll}
\hline Isolate number $^{\mathbf{a}}$ & \multicolumn{1}{c}{ Host of origin } & \multicolumn{1}{c}{ Geographic location } \\
\hline Pr-1 & $\begin{array}{l}\text { Quercus agrifolia } \\
\text { Lithocarpus densiflo- } \\
\text { rus }\end{array}$ & $\begin{array}{l}\text { China Camp State Park, Marin County } \\
\text { Muir Woods, Marin County }\end{array}$ \\
& $\begin{array}{l}\text { L. densiflorus } \\
\text { Pr-5 }\end{array}$ & Marin Municipal Water District, Marin County \\
$\operatorname{Pr}-6$ & Q. agrifolia & Marin Municipal Water District, Marin County \\
$\operatorname{Pr}-7$ & Q. agrifolia & Partrick Road, Napa County \\
\hline
\end{tabular}

a Refers to isolate number in culture collection of D. M. Rizzo, University of California, Davis. All isolates were collected during 2000. 
cumference of the tree. The bark plug then was replaced and covered with sterilized cotton and aluminum foil and wrapped with a layer of duct tape.

On 9 August (14 days), the duct tape, aluminum, and cotton were removed and notes made on bark symptoms. The trees were checked again on 19 September (55 days) and 2 November (99 days) for development of bleeding symptoms. After 132 days, on 5 December 2000, the bark of five trees of each host species was removed. Lesion length and width was measured. Unequal variances among treatments could not be minimized using transformations or weighting; therefore, lesion data were ana- lyzed using the nonparametric tests, Mann-Whitney and Kruskal-Wallis (9). Chips were removed from the phloem cankers and plated on PARP in the field to verify the presence or absence of Phytophthora spp. Plates were incubated in the dark at 20 to $22^{\circ} \mathrm{C}$ and examined within 2 to 5 days.

The five inoculated trees of each host species that were not sampled in December 2000 were examined for the appearance of foliar symptoms on 18 April and 4 September 2001 (approximately 9 and 13 months following inoculation, respectively), but inner bark cankers were not examined.

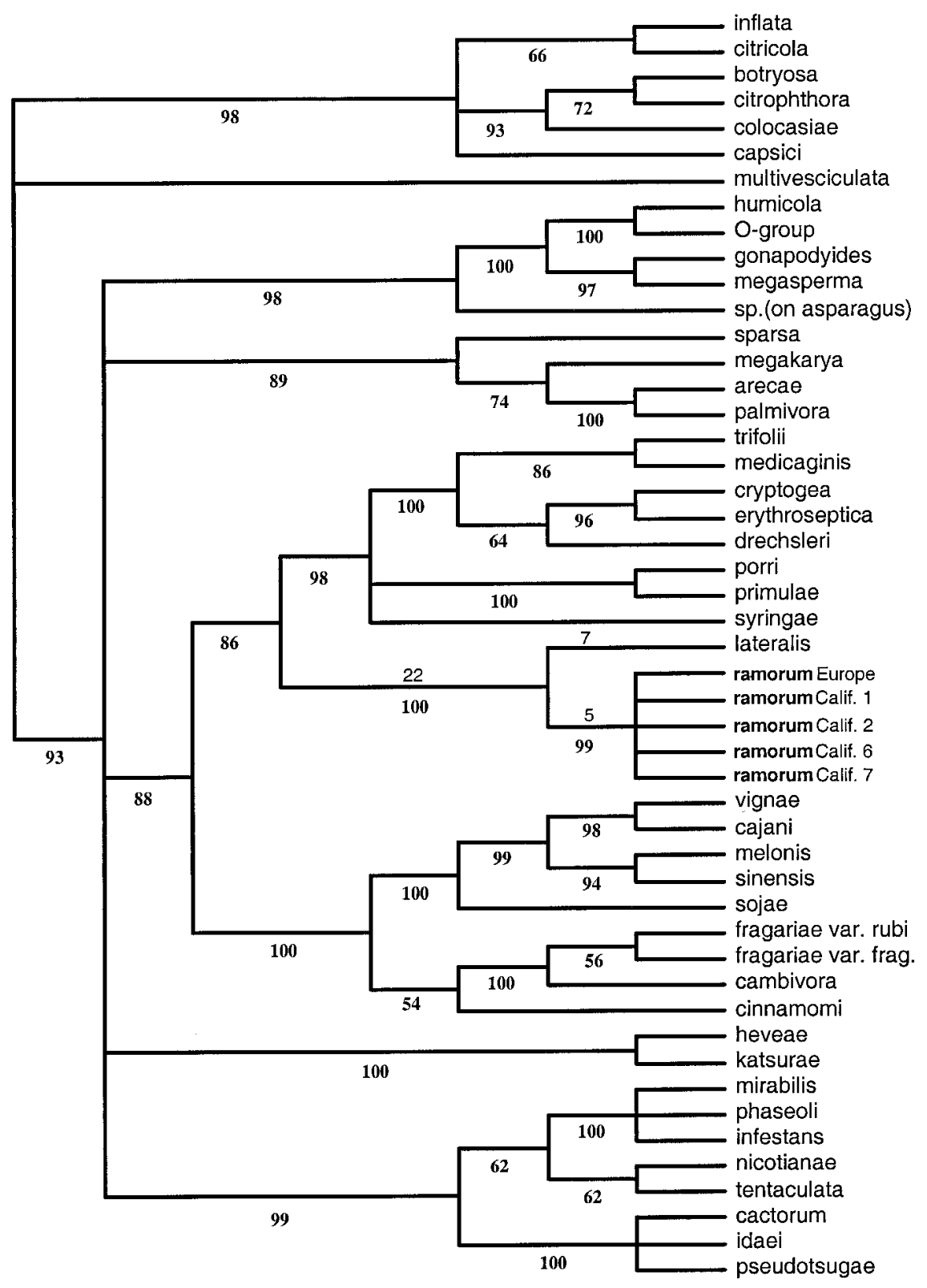

Fig 4. Bootstrap consensus of 12 most parsimonious (MP) trees based on internal transcribed spacer sequences showing the relationship of California isolates of Phytophthora ramorum to European $P$. ramorum and placement within the genus Phytophthora. MP trees' scores were as follows: 860 characters, tree length $=960$ steps, $\mathrm{CI}=0.570, \mathrm{RI}=0.834, \mathrm{HI}=0.430$. Bootstrap values shown in bold under branches; number of steps shown above branches for the P. ramorum clade were identical in all 12 MP trees. Sequences of the European isolate of $P$. ramorum and all California isolates were identical.

\section{RESULTS}

Pathogen isolation and identification. In all, 119 isolates of Phytophthora were obtained from symptomatic or dead $L$. densiflorus and Quercus spp. in coastal areas of California. Based on morphological characters (sporangia, chlamydospores, oospores, and mycelial swellings), the isolates were grouped into three morphotypes.

The most common Phytophthora morphotype (109 isolates) was morphologically uniform but did not match the characteristics of previously described species of Phytophthora (8). Each isolate had caducous (pedicel $<5 \mu \mathrm{m}$ ), sympodial, semipapillate sporangia that were 20 to $80 \mu \mathrm{m}$ long (Fig. 3). Sporangia were readily formed on V8A and in water. All isolates had highly branching hyphae on solid media and formed many hyaline chlamydospores (40 to $80 \mu \mathrm{m}$ in diameter) on all media. In older isolation plates with host material, chlamydospores often turned a cinnamon-brown color (Fig. 3). Chlamydospores were mostly terminal, although some were intercalary. Unpaired California isolates did not form oospores on V8A or CMA. Cultures on V8A and CMA were grown at $15,20,25,30$, and $35^{\circ} \mathrm{C}$. Optimal temperature for mycelial growth was $20^{\circ} \mathrm{C}$, although the extent of growth at 15 and $25^{\circ} \mathrm{C}$ was only slightly less than the extent of growth at $20^{\circ} \mathrm{C}$. Minimal growth was observed at $30^{\circ} \mathrm{C}$ and no growth was observed at $35^{\circ} \mathrm{C}$.

Using primers ITS1 and ITS4, an 860bp fragment was amplified from DNA of four isolates (PR-1, PR-2, PR-6, and PR$7)$, and their sequences were identical (GenBank accession number AY038050). Based on the BLAST search, there was no matching ITS sequence found in the GenBank database, but the nearest sequence was that of $P$. lateralis, which differed by $11 \mathrm{nt}$.

In December 2000, we became aware of an undescribed Phytophthora sp. isolated from rhododendron in Germany and the Netherlands that was morphologically similar to our California oak Phytophthora $\mathrm{sp}$. This rhododendron pathogen was recently described as a new species, Phytophthora ramorum $\mathrm{S}$. Werres \& A. W. A. M. de Cock (32). The ITS sequence (GenBank accession number AF429767) of $P$. ramorum was identical to that of our California oak isolates. All morphological characters of the California isolates were also consistent with $P$. ramorum (32). Parsimony analysis of the ITS sequence data placed the European and California $P$. ramorum isolates in a well-supported clade with P. lateralis (Fig. 4).

A second morphotype was collected from six trees and also did not match any described species of Phytophthora (8). On CMA, the advancing hyphae did not branch as in $P$. ramorum. Sporangia were variable in shape (many oddly shaped), 
papillate, and persistent. No chlamydospores were observed. Amphigynous oospores occasionally were noted in cultures grown on PARP. Although a detailed temperature study was not carried out, the isolates had little or no growth above $20^{\circ} \mathrm{C}$. The ITS sequence of isolates of this second morphotype were three base pairs different from $P$. ilicis (GenBank accession number AJ131990). P. ilicis has only been reported on English holly (Ilex aquifolium) from western North America. It has obpyriform, semipapillate, caducous sporangia, rare chlamydospores, and amphigynous oospores (8). Our second morphotype from oaks appears to be an undescribed Phytophthora sp., and we refer to it here as a $P$. ilicis-like species. The third Phytophthora morphotype was collected from six trees and was identified as $P$. cinnamomi based on morphological characters (8) and ITS sequence data (6).

Field survey. We investigated approximately 200 reports of oak dieback or mortality in 29 of 58 counties in California. The survey was conducted primarily in the coastal counties from Santa Barbara County to Humboldt County, although reports of oak dieback and mortality were investigated in a number of counties in the Central Valley region, Sierra Nevada region, and southern California. In addition, we looked for symptomatic trees while driving over $6,500 \mathrm{~km}$ along roads to those sites.

$P$. ramorum was the only one of the three Phytophthora spp. associated with extensive stand mortality. This species was isolated from cankers on $L$. densiflorus, $Q$. agrifolia, $Q$. kelloggii, and $Q$. parvula var. shrevei. The fungus was isolated from trees that ranged in size from 3 to $80 \mathrm{~cm}$ dbh for $L$. densiflorus, 10 to $105 \mathrm{~cm}$ dbh for $Q$. agrifolia, and 30 to $50 \mathrm{~cm}$ dbh for $Q$. kelloggii. Only one tree of $Q$. parvula var. shrevei $(50 \mathrm{~cm} \mathrm{dbh})$ was found to be infected with $P$. ramorum.

$P$. ramorum was recovered from 42 locations over an area running south to north along approximately $325 \mathrm{~km}$ of the Pacific Coast from Big Sur in Monterey County $\left(36^{\circ} 15^{\prime} \mathrm{N}, 121^{\circ} 47^{\prime} \mathrm{W}\right)$ to southern Mendocino County $\left(38^{\circ} 56^{\prime} \mathrm{N}, 123^{\circ} 19^{\prime} \mathrm{W}\right.$ ) (Fig. $5)$. The sites furthest inland were approximately $70 \mathrm{~km}$ from the coast in Solano County $\left(38^{\circ} 18^{\prime} \mathrm{N}, 122^{\circ} 12^{\prime} \mathrm{W}\right)$ (Fig. 5). Most $P$. ramorum isolates, however, were collected within $30 \mathrm{~km}$ of the Pacific Coast or of San Francisco Bay (Fig. 5). The pathogen was recovered from forests at sea level to $800 \mathrm{~m}$ elevation. Within this large geographic area, the distribution of $P$. ramorum was found to be patchy. Even within the counties (Marin, Santa Cruz, and Sonoma) in which the greatest number of sites were sampled, there were large areas with susceptible hosts species that were apparently disease free. Although not part of our survey, P. ramorum recently has been confirmed in southwestern Oregon approximately $300 \mathrm{~km}$ north of the northernmost site in California (Mendocino County) (E. Hansen, personal communication).

Symptomatic and dead trees associated with $P$. ramorum were found in three different forest types: coast redwood (Sequoia sempevirens) forest and two types of mixed evergreen forests $(1,26)$. Isolates of $P$. ramorum from $L$. densiflorus came primarily from redwood forests in which $L$. densiflorus was a significant component of the understory. The three Quercus spp. and L. densiflorus also occur in closed-canopy, mixed-evergreen forests that can be divided into those with and without a significant component of Douglas fir (Pseudotsuga menziesii), and Phytophthora ramorum was found in both forest types. Other major hardwood associates in these mixed-evergreen forests include California bay laurel (Umbellularia californica) and madrone (Arbutus menziesii). Samples yielding $P$. ramorum were taken mostly from wildland settings, but also at the urban-wildland interface adjacent to houses.

$P$. cinnamomi was isolated from four symptomatic $Q$. agrifolia trees in semiurban areas in Alameda and Contra Costa

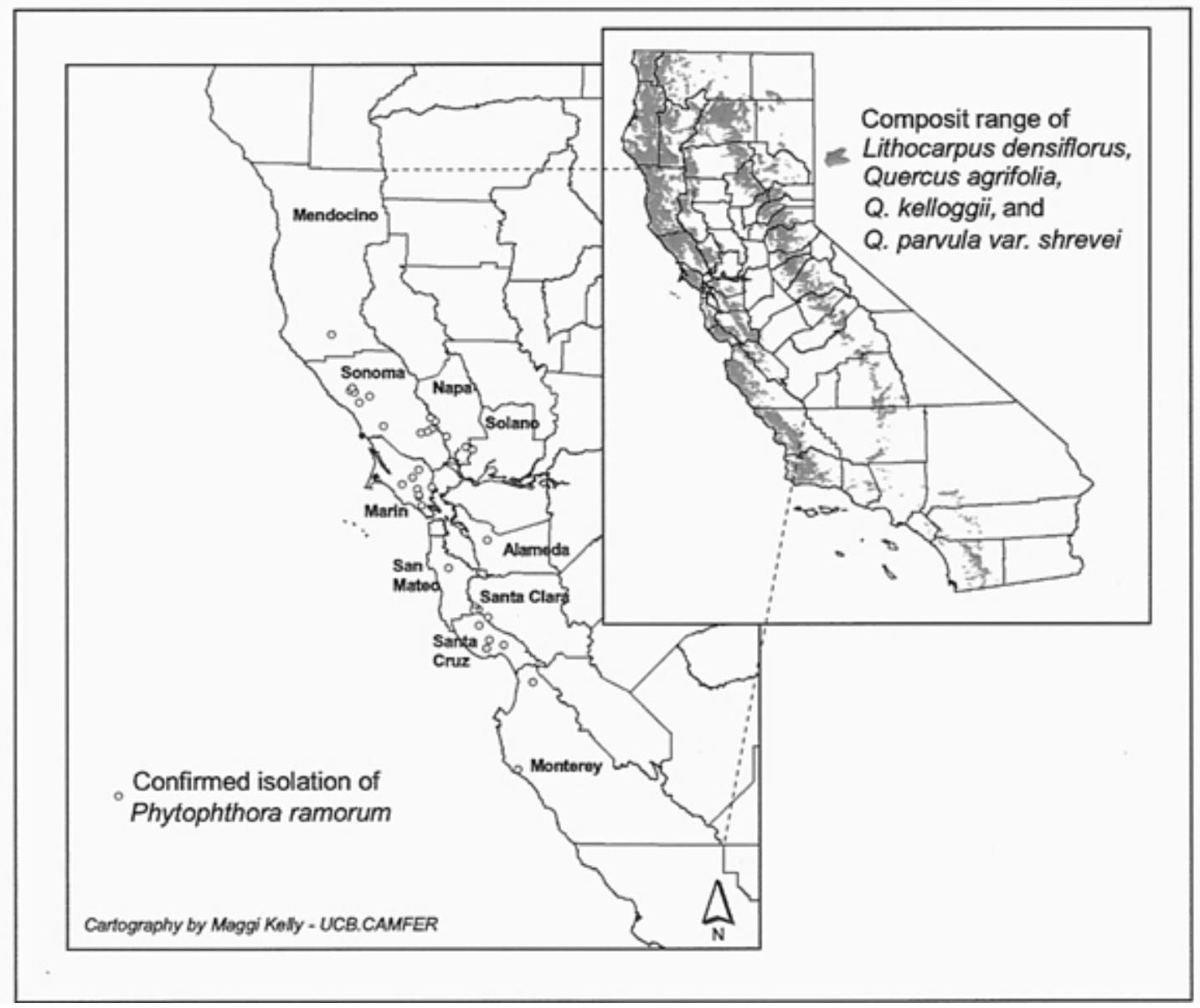

Fig. 5. Distribution of Phytophthora ramorum and susceptible hosts within California. 
Counties (i.e., near developed areas such as sidewalks or houses). Two $P$. cinnamomi isolates were collected from Chrysolepis chrysophylla (golden chinquapin) on a ridge top in Henry Cowell State Park in Santa Cruz County. The P. ilicis-like species was recovered from four $Q$. agrifolia trees in semideveloped areas in Contra Costa County. It was also isolated from symptomatic L. densiflorus trees in Sonoma and Humboldt counties. These two Phytophthora spp. were associated with bleeding cankers on these hosts, but there was not significant tree mortality at these sites.

Although a quantitative survey was not conducted, our field observations suggest that overall tree mortality levels in forests beyond the geographic range of $P$. ramorum were much lower than those within the geographic range. Root disease caused by Armillaria mellea was locally severe in some cases. Canker rots caused by Inonotus andersonii, A. gallica, Omphalotus olivescens, and other wood-decay fungi were noted on many trees and these pathogens may cause much of the noted background mortality outside the apparent range of $P$. ramorum. These pathogens also were observed on trees within the range of $P$. ramorum. Opportunistic organisms commonly observed on trees with advanced $P$. ramorum infections included ambrosia beetles (Monarthrum scutellare and $M$. dentiger), bark beetles (Pseudopityophthorus pubipennis), and a sapwood rotting xylariaceous ascomycete, Hypoxylon thouarsianum (20).

Disease description. Phytophthora ramorum was isolated from cankers on mature Quercus spp. and L. densiflorus trees at the root crown to $20 \mathrm{~m}$ above the ground. Although cankers often appeared to be initiated at the basal part of the tree, they did not extend below the soil line and were not found in the roots except on portions of buttress roots if they were above the soil line. Based on observations of cankers in different stages of development, infection appeared to begin in the outer bark and progress to the cambium, and eventually the xylem. Infection and discoloration generally were more extensive in cambium and secondary phloem tissues than in the xylem. In active cankers, the phloem was discolored slightly or to various shades of brown, and cankers were delimited by thin black lines (Fig. 2). On some cankers, black discoloration was observed up to $3 \mathrm{~cm}$ into the xylem, but, more typically, discoloration extended less than $1 \mathrm{~mm}$ into xylem tissues. Individual cankers extended to over $2 \mathrm{~m}$ in length. $P$. ramorum typically was isolated from the margins of these discolored areas, although it often was isolated from older portions of the cankers as well.

$P$. ramorum was isolated from branches as small as $5 \mathrm{~mm}$ in diameter on $L$. densiflorus. Saplings and understory trees of $L$. densiflorus often had many branch cankers, but no basal cankers were observed. Branches above cankers often were wilted while branches below the cankers were asymptomatic. Cankers on small $L$. densiflorus stems and branches were not as distinct as those on the main stem of larger trees and zone lines were not always apparent in either the phloem or xylem. $P$. ramorum was isolated from the margins of discoloration in the cambium and phloem, but was not consistently isolated from all such cankers. No Q. agrifolia or $Q$. kelloggii saplings were found on the sites we sampled.

Seedling and sapling inoculation trials. In both trials, $P$. ramorum caused lesions on $L$. densiflorus and $Q$. agrifolia seedlings that were significantly greater than those on the controls $(P<0.05)$ (Table $2)$. On seedlings inoculated with $P$. ramorum, the external surface of the bark was sunken along the entire length of internal colonization by the pathogen. Inter- nal discoloration generally was limited to the phloem, although some xylem discoloration was apparent. Lesions progressed both up and down from the wound, but lesion lengths were greater above the wound. Of $20 \mathrm{~L}$. densiflorus inoculated seedlings, 10 were girdled by the pathogen. Four of these seedlings died, two showed wilting symptoms, and four had no apparent foliar symptoms. Two inoculated seedlings of $L$. densiflorus showed wilting symptoms but were not girdled by $P$. ramorum. On three $L$. densiflorus seedlings in the second trial, the pathogen grew through petioles of leaves near the inoculation point and was isolated from leaf lesions. No $Q$. agrifolia seedlings died during either of the trials. Limited foliar symptoms were noted on Q. agrifolia; only four inoculated seedlings showed signs of chlorosis or tip wilting. In both trials, $P$. ramorum caused lesions on $L$. densiflorus seedlings that were significantly longer than those on $Q$. agrifolia seedlings $(P<$ 0.05 ) (Table 2). Inoculation wounds on the control plants formed callus tissue that sealed the wound. P. ramorum was recovered from all inoculated $L$. densiflorus and $Q$. agrifolia seedlings and none of the controls.

In the $Q$. agrifolia sapling inoculation trials, no plants died and no foliar symptoms were noted. In each of the trials, $P$. ramorum caused lesions that were significantly greater than those found on the controls (Table 3). During the trial initiated in October, two of the saplings were girdled and two were nearly girdled, although no foliar symptoms were noted. Inoculation wounds on the controls formed callus tis-

Table 3. Mean and range in lesion length in Quercus agrifolia saplings resulting from inoculations with Phytophthora ramorum

\begin{tabular}{|c|c|c|c|c|c|c|}
\hline \multirow[b]{3}{*}{ Isolate } & \multicolumn{6}{|c|}{ Lesion length $(\mathrm{cm})^{\mathbf{a}}$} \\
\hline & \multicolumn{2}{|c|}{ Trial 1} & \multicolumn{2}{|c|}{ Trial 2} & \multicolumn{2}{|c|}{ Trial 3} \\
\hline & Mean & Range & Mean & Range & Mean & Range \\
\hline P. ramorum $\operatorname{Pr}-5$ & 4.7 & $2.6-6.3$ & 9.0 & $3.4-17.1$ & 6.6 & $3.1-10.4$ \\
\hline Control & 0.8 & $0.7-0.9$ & 0.8 & $0.7-0.9$ & 0 & 0 \\
\hline
\end{tabular}

${ }^{a}$ Mean and range of lesion lengths on five saplings per treatment for each trial. Lesions lengths were measured after 204 days in trial 1, 125 days in trial 2, and 150 days in trial 3. Mean lesion length in P. ramorum-inoculated seedlings was significantly greater than that of controls in all trials at $P<$ 0.05 (analysis of variance).

Table 2. Mean and range in lesion length in Lithocarpus densiflorus and Quercus agrifolia seedlings resulting from inoculations with Phytophthora ramorum

\begin{tabular}{|c|c|c|c|c|c|c|c|c|}
\hline \multirow[b]{4}{*}{ Isolate } & \multicolumn{8}{|c|}{ Lesion length $(\mathrm{cm})^{\mathrm{a}}$} \\
\hline & \multicolumn{4}{|c|}{ Lithocarpus densiflorus } & \multicolumn{4}{|c|}{ Quercus agrifolia } \\
\hline & \multicolumn{2}{|c|}{ Trial 1} & \multicolumn{2}{|c|}{ Trial 2} & \multicolumn{2}{|c|}{ Trial 1} & \multicolumn{2}{|c|}{ Trial 2} \\
\hline & Mean & Range & Mean & Range & Mean & Range & Mean & Range \\
\hline P. ramorum $\operatorname{Pr}-5$ & 5.1 & $2.1-12.3$ & 4.1 & $2.1-6.0$ & 1.7 & $1.3-1.9$ & 2.7 & $1.9-3.7$ \\
\hline P. ramorum $\mathrm{Pr}-6$ & 4.1 & $1.9-9.0$ & 3.6 & $1.7-5.5$ & 2.3 & $1.7-5.5$ & 1.9 & $1.3-2.2$ \\
\hline Control & 0.7 & $0.1-1.0$ & 1.2 & $0.9-1.5$ & 0.5 & $0.1-0.7$ & 1.0 & $0.7-1.4$ \\
\hline
\end{tabular}

${ }^{\mathrm{a}}$ Mean and range of lesion lengths based on 10 seedlings per treatment for each trial. Lesions lengths were measured after 65 days in trial 1 and 40 days in trial 2. Mean lesion lengths in seedlings inoculated with P. ramorum Pr-5 and Pr-6 were both significantly greater in both trials and in both hosts than those of control inoculations at $P<0.05$ based on analysis of variance (ANOVA) with contrasts. Mean lesion lengths caused by $P$. ramorum were significantly different between $L$. densiflorus and $Q$. agrifolia at $P<0.05$ (ANOVA). 
sue that sealed the wound. $P$. ramorum was recovered from all inoculated saplings, but none of the controls.

Mature tree inoculations. Oozing sap was first observed from the bark around the inoculation point on four $Q$. agrifolia trees 3 weeks after inoculation. On 19 September, bleeding was seen up to $5.5 \mathrm{~cm}$ from the inoculum point. By 5 December, each of the 10 inoculated $Q$. agrifolia trees showed sap bleeding around the inoculation points. Bleeding extended up to $35 \mathrm{~cm}$ from the inoculation point. No bleeding was observed on the control trees. Bleeding was observed on a $L$. densiflorus tree on 5 December, but the bleeding was very limited and restricted to an area near the inoculum plug.

After 4 months, $P$. ramorum caused lesions on both hosts that were significantly greater than those on the controls $(P<$ 0.05; Table 4). In general, cankers were elliptical to circular in shape (Fig. 6). Distinct black lines were evident at the canker margins on $Q$. agrifolia (Fig. 6). Phloem cankers on $L$. densiflorus did not have as distinct a margin as those found on $Q$. agrifolia. Discoloration was evident into the xylem of both host species. The cankers from isolates PR-5 and PR-6 merged to girdle a $Q$. agrifolia tree $(25 \mathrm{~cm} \mathrm{dbh})$ and two L. densiflorus trees ( 25 and $44 \mathrm{~cm}$ dbh). No foliar symptoms or the presence of opportunistic fungi or bark beetles were noted on any of the inoculated trees on 5 December. $P$. ramorum was reisolated from all $Q$. agrifolia cankers, including the smallest canker (3.8 cm length). On $L$. densiflorus, the smallest canker $(1.8 \mathrm{~cm}$ length) was the only canker from which $P$. ramorum was not recovered; however, the other canker on this same tree was $47.8 \mathrm{~cm}$ in length. Lesions caused by $P$. ramorum were not significantly different in length $(P$ $<0.05$ ) between inoculated $L$. densiflorus and Q. agrifolia trees (Table 4). Control wounds on both hosts resulted in only slight discoloration around the wound. There was no distinct margin surrounding the discoloration on controls. The control wounds on three trees were overrun by the enlarging cankers of $P$. ramorum. With the exception of these controls, $P$. ramorum was not recovered from any of the control wounds.

On 18 April 2001 (9 months after inoculation), three of the five inoculated $Q$. agrifolia trees not sampled in December had no foliar symptoms, but two trees were showing signs of crown thinning. Based on the extent of outer bark discoloration and external bleeding, three of the five $Q$. agrifolia trees also appeared to be girdled. Ambrosia beetles (Monarthrum sp.) had colonized three trees. Beetles had penetrated only into the inoculation sites of two trees; one tree was extensively colonized outside the inoculation area. By September 2001 (13 months after inoculation), two trees had brown foliage, one tree was still green but faded, and two trees had no apparent foliar symptoms. Four of the five trees had extensive bleeding and appeared to be girdled. Cankers on two trees appeared to be over $1 \mathrm{~m}$ in length. Based on external symptoms, canker development on one tree appeared to be minimal, with sap bleeding only $20 \mathrm{~cm}$ from the two inoculation points. All five trees had evidence of ambrosia beetle activity at 13 months. One tree had small fruiting bodies of Hypoxylon thouarsianum forming on the canker face.

On 18 April 2001, two of five inoculated L. densiflorus trees not sampled in December had crown thinning, but the foliage had not turned brown on any tree. External bleeding symptoms still were limited compared with $Q$. agrifolia; however, one inoculated $L$. densiflorus tree had extensive bleeding and appeared to be girdled. Two trees had evidence of minor insect activity, most likely buprestid or cerambycid borers rather than ambrosia or bark beetles. By September 2001, three trees had brown foliage, one had faded green foliage and extensive branch dieback, and one tree had no foliar symptoms. The four trees with foliar symptoms had been extensively colonized by ambrosia and bark beetles.

\section{DISCUSSION}

In this article, we have described a new canker disease of $L$. densiflorus and Quercus spp. caused by the recently described species $P$. ramorum. This disease has reached epidemic proportions in coastal California; preliminary surveys have found $50 \%$ or more of the trees diseased in many forest stands (12). Although other species of Phytophthora occasionally were recovered in our field surveys, none was found at more than a few sites and none was associated with extensive tree mortality in wildland situations. In contrast, $P$. ramorum has been recovered from many sites in several different forest types over an area that runs approximately $600 \mathrm{~km}$ south to north from central California to

Table 4. Mean and range in lesion length after 132 days in Lithocarpus densiflorus and Quercus agrifolia mature trees resulting from inoculations with Phytophthora ramorum

\begin{tabular}{|c|c|c|c|c|}
\hline \multirow[b]{3}{*}{ Isolate } & \multicolumn{4}{|c|}{ Lesion length $(\mathrm{cm})^{\mathrm{a}}$} \\
\hline & \multicolumn{2}{|c|}{ Lithocarpus densiflorus } & \multicolumn{2}{|c|}{ Quercus agrifolia } \\
\hline & Mean & Range & Mean & Range \\
\hline P. ramorum $\operatorname{Pr}-5$ & 41.1 & $1.8-71.3$ & 32.4 & $3.7-57.4$ \\
\hline P. ramorum $\operatorname{Pr}-6$ & 42.3 & $14.6-61.6$ & 25.0 & $9.4-57.0$ \\
\hline Control & 1.9 & $1.6-2.8$ & 1.6 & 1.6 \\
\hline
\end{tabular}

a Mean and range of lesion lengths on five trees per treatment. Mean lesion lengths in trees inoculated with $P$. ramorum $0-13$ and $0-16$ in both hosts were significantly greater than those of control inoculations at $P<0.05$ based on analysis of variance (ANOVA) with contrasts. Mean lesion lengths caused by $P$. ramorum were not significantly different between $L$. densiflorus and $Q$. agrifolia at $\mathrm{P}<0.05$ (ANOVA).

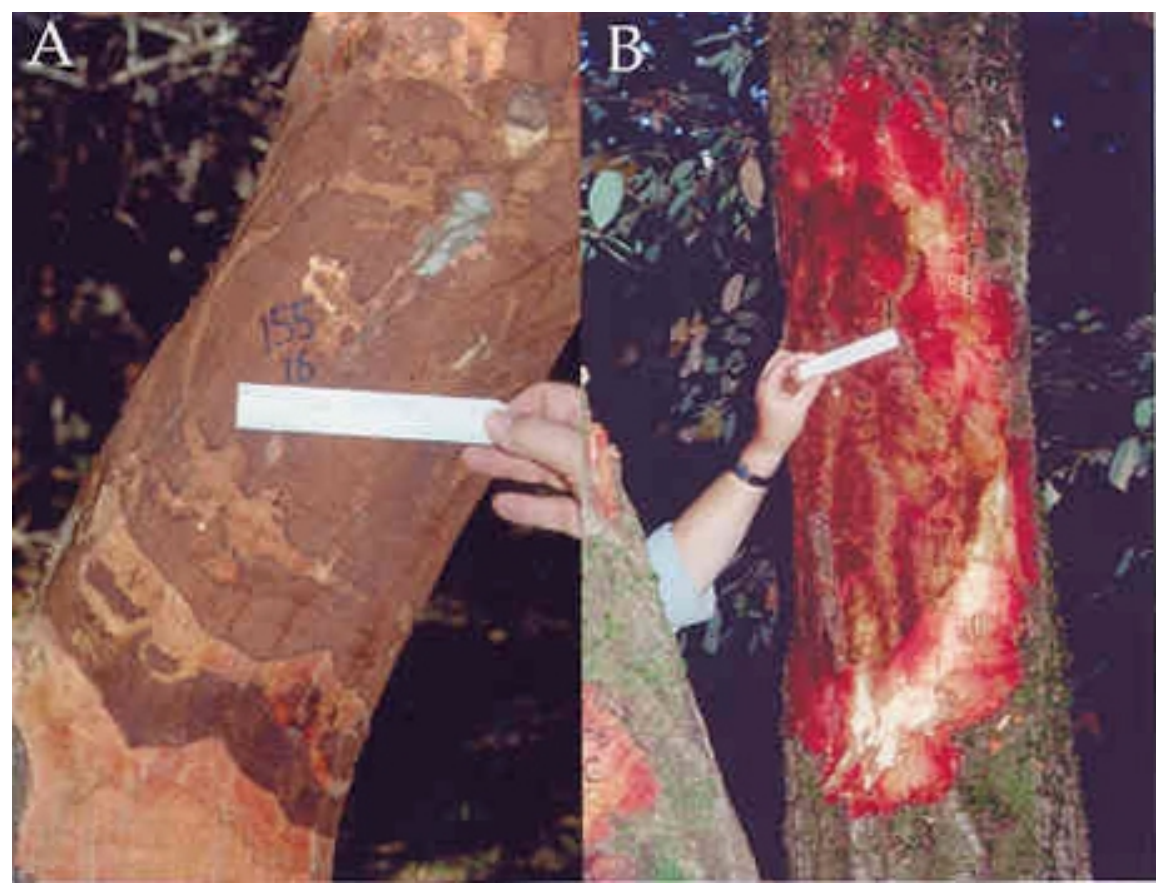

Fig. 6. Phloem cankers produced on mature trees 4 months following inoculation with Phytophthora ramorum. Bark was removed to better show canker development. A, Quercus agrifolia. Canker length is $57 \mathrm{~cm}$. B, Lithocarpus densiflorus. Canker length is $71.3 \mathrm{~cm}$. 
southern Oregon. Inoculations of $L$. densiflorus and $Q$. agrifolia in the field and greenhouse resulted in symptoms similar to those observed in the field, which confirmed the pathogenicity of $P$. ramorum. Although the name "sudden oak death" is well entrenched in the popular press, we believe that it may not be an appropriate common name for the disease. The onset of symptoms is not always "sudden" and the disease does not always result in death of the tree. $P$. ramorum causes cankers exclusively on aerial plant parts; therefore, we propose the common name of Phytophthora canker to distinguish this new disease from Phytophthora root and crown rot caused by other species of Phytophthora.

Culture morphology and ITS sequences clearly support the identification of the pathogen as $P$. ramorum (32). Previously, $P$. ramorum has only been reported on ornamental Rhododendron and Viburnum spp. in Germany and the Netherlands (31,32). More detailed comparisons of California and European isolates are ongoing ( $\mathrm{S}$. Werres, personal communication).

Based on ITS sequences, $P$. ramorum falls into a clade of primarily nonpapillate and semipapillate, soilborne species, including $P$. lateralis, $P$. drechsleri, $P$. cryptogea, and $P$. syringae (6). $P$. ramorum shares phenotypic characters with a number of the species within this clade. The color, size, and attachment of the chlamydospores and the temperature requirements are very similar to those of $P$. lateralis, the closest relative based on ITS sequence analysis. However, P. lateralis has nondeciduous, nonpapillate sporangia and is a root pathogen. $P$. ramorum is the only member of this clade with distinctly caducous sporangia. However, P. lateralis occasionally has been observed to form deciduous sporangia (32) and has been reported to cause foliar infections due to direct splash of propagules from the soil (30). $P$. syringae also is reported to cause aerial cankers on woody hosts $(7,8)$, although its sporangia are considered to be noncaducous and it does not form chlamydospores.

The geographic origin of $P$. ramorum is unknown (32). Its aggressiveness on $L$. densiflorus of all ages and its limited geographic range in relation to the range of all susceptible hosts (Fig. 5) suggest that it may be a recently introduced exotic or invasive species in California. The relationship between the California oak pathogen and the rhododendron pathogen from Europe is not clear. We recently have recovered $P$. ramorum from Rhododendron spp. in a nursery in Santa Cruz County (12). It is not known if the pathogen was transported between the two continents on ornamental plants or was introduced into both locations from a third, as yet unknown, location. The phylogenetic relationship between $P$. ramorum and $P$. lateralis may provide clues to the origin of both pathogens. $P$. lateralis is presumed to be an exotic species currently causing significant mortality of Port-Orford cedar (Chamaecyparis lawsoniana) in native stands of southern Oregon and northern California (15). The origin of P. lateralis is unknown; to date, it has only been found in the $\mathrm{Pa}$ cific Northwest states of the United States and once in France (15). The close genetic relationship between $P$. lateralis and $P$. ramorum suggests that both of these pathogens may have originated from the same geographic area.

We cannot completely dismiss the hypothesis that $P$. ramorum has been in California for many years, but that changes in the environment have led to an increase in its aggressiveness or prevalence. Such changes in environmental conditions might include climate change, fire suppression, or other changes in land use patterns. In Europe, it appears that many oak forests have resident populations of Phytophthora spp. that have remained undetected $(14,17)$. Many of these species probably cause fine root death, reductions in growth rates, and occasional mortality of trees without causing the large-scale mortality often associated with exotic pathogens. However, under different environmental conditions these species may become ecologically very important (14).

Another potential hypothesis is a change in host specificity or host preferences by a local Phytophthora sp. Phytophthora hybrids are thought to occur in nature and may show a marked change in host range (4). In England and other areas in Europe, a new Phytophthora sp. that appears to be a hybrid between $P$. cambivora and $P$. fragariae-like isolates has caused the mortality of thousands of alder trees (Alnus spp.; 4). Although a hybrid origin of $P$. ramorum is possible and somewhat supported by its unique morphological traits, the lack of a heterozygous pattern in the ITS sequences suggests that these isolates do not represent first generation hybrids (M. Garbelotto, unpublished data).

Although the symptomatology of the disease is very similar to that caused by other Phytophthora spp. on oaks, $P$. ramorum differs by its exclusive aerial biology. Although some Phytophthora spp. (e.g., P. citricola, P. cactorum, and $P$. cinnamomi) may move into the main stem and eventually cause aerial cankers on oaks, they generally start infections in the roots or root crown area $(3,21)$. Other Phytophthora spp., such as the newly described $P$. quercina in Europe, appear to be exclusively associated with oak roots (17). Although we have recovered the pathogen from soil and litter (J. M. Davidson, unpublished data), we have not observed symptoms on or isolated $P$. ramorum from roots below the soil line. We also have isolated $P$. ramorum up to $20 \mathrm{~m}$ above the ground from the stems of trees that had no basal cankers. The aerial nature of the disease is most striking in areas in which L. densiflorus regeneration, growing underneath larger infected trees, shows multiple scattered cankers in the upper branches. Observations of the disease on Rhododendron spp., Viburnum spp., and other hosts also indicate that the pathogen infects stems, branches, or leaves, rather than the roots $(31,32$, unpublished data).

Empirical studies are ongoing to determine how the pathogen is spread in the forest. We have recovered $P$. ramorum from rainwater collected around diseased trees (J. M. Davidson, unpublished data), indicating that the pathogen can move via rain splash or wind-driven rain as with other aerially dispersed species of Phytophthora (e.g., P. palmivora; 8). However, sporangia and chlamydospores have not been directly observed on canker surfaces on Quercus spp. or L. densiflorus. Assuming that $P$. ramorum is an exotic species, we do not know how $P$. ramorum has managed to spread over $600 \mathrm{~km}$ along the California coast and to Oregon since the disease was first noted. Most Phytophthora spp. are moved long distances in infected plant material or soil, or by flowing water (8). P. ramorum could be moved on ornamental hosts, such as rhododendrons, or firewood. The first report of $L$. densiflorus mortality in Marin County in 1994 was subsequently found to be associated with a planting of ornamental rhododendron in the understory several years before. We also have isolated the pathogen from trees for up to 2 months after felling, but the capacity of the pathogen to be spread in firewood is unknown.

The current geographic range of the disease includes a wide range of forest types and microclimates within California's Mediterranean climate of predominantly winter rainfall. Mean annual rainfall at different locations where $P$. ramorum has been collected ranges from 85 to $200 \mathrm{~cm}$. Coastal areas also receive cool, moist air throughout the year, including summer fogs that can deposit moisture on plant surfaces. Higher elevation sites further inland also are often immersed in cloud cover for extended periods. Based on the cool temperature requirements of the pathogen, climate may play a significant role in determining the spread and distribution of the pathogen. Although drier inland and southern areas in California may not have favorable environmental conditions during summer months, there is the potential for the pathogen to become established during cool, wet winter months. Such a situation has been described for $P$. syrin$g a e$, which also has a relatively cool temperature optimum. P. syringae may be very prevalent in almond orchards of the Central Valley of California during the winter months, but is not detectable during the hot, dry summer months (7). Occasional El Niño years, when rainfall is substantially higher and lasts longer into the dry season, 
might also allow for expansion of $P$. ramorum into drier inland areas. In preliminary laboratory tests, $P$. ramorum was capable of surviving when petri plates were exposed to $40^{\circ} \mathrm{C}$ for $4 \mathrm{~h}$ and to $45^{\circ} \mathrm{C}$ for $1 \mathrm{~h}$ (M. Garbelotto, unpublished data), suggesting that warmer temperatures alone may not restrict pathogen survival.

Based on field observations and our inoculation studies with seedlings and mature trees, L. densiflorus appears to be more susceptible to infection by $P$. ramorum than is $Q$. agrifolia. In the seedling inoculations, only $L$. densiflorus showed foliar symptoms and mortality within 8 weeks. This corresponds to field observations of branch flagging (death of small branches) and isolation of $P$. ramorum from smaller branches of understory L. densiflorus. Small branch flagging has not been observed and $P$. ramorum has not been isolated from small branches on Quercus spp. In the seedling inoculations, $Q$. agrifolia was infected and the pathogen recovered, but the disease did not progress very far. In inoculated mature trees, both $L$. densiflorus and $Q$. agrifolia were infected, but there was substantial variation in canker lengths with individual inoculations. Overall, the inoculated $L$. densiflorus consistently had larger cankers than did $Q$. agrifolia, although these differences were not statistically significant.

All of the known susceptible Quercus spp. are in the red oak group (section Lobatae; 23). No species in the white oak group (section Quercus) or golden cup group (section Protobalanus) have been found with the disease. Q. lobata (valley oak, in the white oak group) occasionally co-occurs with diseased $Q$. agrifolia, but symptomatic $Q$. lobata trees have not been observed (20). In addition to the reports of $P$. ramorum on Rhododendron spp. and Viburnum spp. in Europe $(31,32)$, we recently have isolated $P$. ramorum from ornamental Rhododendron spp. and native Vaccinium ovatum, Arbutus menziesii, and Umbellularia californica within the geographic range of the pathogen in California (unpublished data). The ability of $P$. ramorum to attack host species in diverse plant families (i.e., Fagaceae, Ericaceae, Lauraceae, and Caprifoliaceae) suggests that we have not yet found the complete host range of the pathogen in native forests of California.

Exotic species of Phytophthora have been considered responsible for extensive tree mortality and negative ecological impact in forests of Australia, Europe, and North America $(3,13,22)$. Based on these past case studies, the disease caused by $P$. ramorum has the potential to cause longterm landscape changes in California oak forests. $P$. ramorum has only recently been described; therefore, basic information on its biology and ecology are scant. Efforts are underway by numerous scientists to evaluate the ecological impacts of the dis- ease on the many forest ecosystems in California and monitor its spread and impact (18). Of additional concern is the possibility that the pathogen would spread to oak forests of the eastern United States. The susceptibility of eastern red oaks, such as $Q$. rubra and $Q$. palustris, is unknown.

Control of Phytophthora spp. in natural forests is very difficult. Use of fungicides or manipulation of water levels, as is done in cultivated areas, often is not feasible. Most efforts in managing exotic Phytophthora spp. in natural forests, therefore, have been directed at avoiding spread of the pathogen to new areas. This has been done by restricting access to forests or by providing wash stations for vehicles leaving or entering quarantined areas $(15,33)$. Although this strategy has worked relatively well in rural Australia, southern Oregon, and northern California, it will be very difficult to implement such measures in the central coastal area of California, where the population in the affected areas approaches six million people. Nonetheless, without a detailed knowledge of the extent of the infested area and the mode of spread of $P$. ramorum, the design of any management strategies, including regulatory, will be difficult at best.

\section{ACKNOWLEDGMENTS}

We thank B. McPherson, J. Wakeman, A. Wickland, J. Warren, S. Swain, C Friel, S. Murphy, K. Hayden, M. Meija-Chang, D. Schmidt, L. Callahan, L. Chappellet, S. Hammond, and E. Lauritzen for technical assistance with various aspects of the lab and field work; M. Swezy and the Marin Municipal Water District for their cooperation in setting up field trials; P. Svirha, N. Palkovsky, M. Kelly, S. Tjosvold, J. Marshall, S. Zack, R. Gross, and many county agriculture and extension personnel for directing us to sampling areas; J. Mircetich, E. Hansen, C. Brasier, G. Browne, and L. Englander for insights on Phytophthora spp. and advice; C. Brasier for pointing out the possible connection with the European rhododendron Phytophthora sp.; S. Werres, R. Baayen, and P. Bonants for invaluable cooperation and collaboration in determining the identity of P. ramorum; $\mathrm{S}$. Frankel, T. Swiecki, D. Wood, A. Storer, and K. Julin for discussions on oak mortality in California; W. Roberts for identification of oak samples; M. Kelly, K. Julin, and K. Parker for providing several of the figures; and T. Harrington and an anonymous reviewer for comments on the manuscript.

\section{LITERATURE CITED}

1. Barbour, M. G., and Major, J., eds. 1988. Terrestrial Vegetation of California. California Native Plant Society, Sacramento, CA.

2. Brasier, C. M. 1992. Oak tree mortality in Iberia. Nature 360:539.

3. Brasier, C. M. 2000. The role of Phytophthora pathogens in forests and semi-natural communities in Europe and Africa. Pages 6-13 in: Phytophthora Diseases of Forest Trees. E. M. Hansen and W. Sutton, eds. Forest Research Laboratory, Oregon State University, Corvallis.

4. Brasier, C. M., Cooke, D. E. L., and Duncan, J. M. 1999. Origin of a new Phytophthora pathogen through interspecific hybridization. Proc. Natl. Acad. Sci. USA 96:5978-5883.

5. Brasier, C. M., Robredo, F., and Ferraz, J. F. P. 1993. Evidence for Phytophthora cinnamomi involvement in Iberian oak decline. Plant Pathol. 42:140-145

6. Cooke, D. E. L., Drenth, A., Duncan, J. M., Wagels, G., and Brasier, C. M. 2000. A molecular phylogeny of Phytophthora and related oomycetes. Fungal Gen. Biol. 30:17-32.

7. Doster, M. A., and Bostock, R. M. 1988. Incidence, distribution, and development of pruning wound cankers caused by Phytophthora syringae in almond orchards in California. Phytopathology 78:468-472.

8. Erwin, D. C., and Ribeiro, O. K. 1996. Phytophthora Diseases Worldwide. American Phytopathological Society Press, St. Paul, MN.

9. Fowler, J. Cohen, L., and Jarvis, P. 1998. Practical Statistics for Field Biology. John Wiley \& Sons. West Sussex, England.

10. Gallego, F. J., Perez de Algaba, A., and Frenandez-Escobar, R. 1999. Etiology of oak decline in Spain. Eur. J. For. Pathol. 29:17-27.

11. Garbelotto, M., Ratcliff, A., Bruns, T. D., Cobb, F. W., Jr., and Otrosina, W. J. 1995. Use of taxon specific competitive priming PCR to study host specificity, hybridization, and intergroup gene flow. Phytopathology 86:543551.

12. Garbelotto, M., Svihra, P., and Rizzo, D. M. 2001. Sudden oak death syndrome fells three oak species. Calif. Agric. 55(1):9-19.

13. Hansen, E. M. 2000. Phytophthora in the Americas. Pages 23-27 in: Phytophthora Diseases of Forest Trees. E. M. Hansen and W. Sutton, eds. Forest Research Laboratory, Oregon State University, Corvallis.

14. Hansen, E. M., and Delatour, C. 1999. Phytophthora species in oak forests of north-east France. Ann. For. Sci. 56:539-547.

15. Hansen, E. M., Goheen, D. J., Jules, E. S., and Ullian, B. 2000. Managing Port-Orford cedar and the introduced pathogen Phytophthora lateralis. Plant Dis. 84:4-13.

16. Hecht-Poinar, E. I., Britton, J. C., and Parmeter, J. R. 1981. Dieback of oaks in California. Plant Dis. 65:281.

17. Jung, T., Cooke, D. E. L., Blaschke, H., Duncan, J. M., and Oßwald, W. 1999. Phytophthora quercina sp. nov., causing root rot of European oaks. Mycol. Res. 103:785-798.

18. Kelly, N. M., and McPherson, B. A. 2001. Multi-scale approaches taken to SOD monitoring. Calif. Agric. 55(1):15-16.

19. Levene, H. 1960. Robust tests for equality of variance. Pages 278-292 in: Contributions to Probability and Statistics. I. Olkin, ed. Stanford University Press, Palo Alto, CA.

20. McPherson, B. A., Wood, D. L., Storer, A. J. Svirha, P., Rizzo, D. M., Kelly, N. M., and Standiford, R. B. 2000. Oak Mortality Syndrome: Sudden Death of Oaks and Tanoaks. Calif. Dep. For. Tree Note No. 26.

21. Mircetich, S. M., Campbell, R. N., and Matheron, M. E. 1977. Phytophthora trunk canker of coast live oak and cork oak trees in California. Plant Dis. Rep. 61: 66-70.

22. Old, K., and Dudzinski, M. 2000. Phytophthora in forests and native vegetation in Australasia and eastern Asia. Pages 14-22 in: Phytophthora Diseases of Forest Trees. E. M. Hansen and W. Sutton, eds. Forest Research Laboratory, Oregon State University, Corvallis.

23. Pavlik, B. M., Muick, P. C., Johnson, S. G., and Popper, M. 1991. Oaks of California. Cachuma Press, Los Olivos, CA.

24. Robin, C., Desprez-Loustau, M. L., and Delatour, C. 1992. Factors influencing the enlargement of trunk cankers of Phytophthora cinnamomi in red oak. Can. J. For. Res. 22:367-374.

25. SAS. 1995. JMP Statistics and Graphics Guide: Version 3.1. SAS Institute Inc., Cary, NC. 
26. Shuford, W. D., and Timossi, I. C. 1989. Plant Communities of Marin County. California Native Plant Society, Sacramento, CA.

27. Swofford D. L. 2000. PAUP: Phylogenetic Analysis Using Parsimony and other methods, Version 4.0b2. Sinauer Associates, Sunderland, MA.

28. Tainter, F. H., O’Brien, J. G., Hernández, A., Orozco, F., and Rebolledo, O. 2000. Phytophthora cinnamomi as a cause of oak mortality in the State of Colima, Mexico. Plant Dis. 84:394-398.

29. Tietje, W., Weitkamp, W., Jensen, W., and
Garcia, S. 1993. Drought takes toll on central coast's native oaks. Calif. Agric. 47(6):4-6.

30. Trione, E. J., and Roth, L. F. 1957. Aerial infection of Chamaecyparis by Phytophthora lateralis. Plant Dis. Rep. 41:211-215.

31. Werres, S., and Marwitz, R. 1997. Triebsterben an Rhododendron: Unbekannte Phytophthora. Dtsch. Gartenbau 21:1166-1168.

32. Werres, S., Marwitz, R., Man In'T Veld, W. A., De Cock, A. W. A. M., Bonants, P. J. M., De Weerdt, M., Themann, K., Ilieva, E., and Baayen, R. P. 2001. Phytophthora ramorum sp. nov., a new pathogen on Rhododendron and Viburnum. Mycol. Res. 105:1155-1165.

33. Weste, G., and Marks, G. C. 1987. The biology of Phytophthora cinnamomi in Australasian forests. Annu. Rev. Phytopathol. 25:207-229.

34. White, T. J., Bruns, T. D., Lee, S., and Taylor, J. 1990. Amplification and direct sequencing of fungal ribosomal RNA genes for phylogenetics. Pages 315-322 in: PCR Protocols-A Guide to Methods and applications. M. A. Innis, D. H. Gelfand, J. J Sninsky, and T. J. White, eds. Academic Press, San Diego, CA. 